\title{
PENDIDIKAN DALAM KELUARGA
}

\author{
Hidayatus Syarifah
}

Sekolah Tinggi Ilmu Tarbiyah Raudhatul Ulum Sakatiga

Email: hidayatussyarifah84@gmail.com

\begin{abstract}
Abstrak
Keluarga adalah sebagai sebuah institusi yang terbentuk karena ikatan perkawinan. Di dalamnya hidup bersama pasangan suami-istri secara sah karena pernikahan. Mereka hidup bersama sehidup semati, ringan sama dijinjing, berat sama dipikul, selalu rukun dan damai dengan suatu tekad dan cita-cita untuk membentuk keluarga bahagia dan sejahtera lahir dan batin.

keluarga memiliki nilai strategis dalam memberikan pendidikan nilai kepada anak, terutama pendidikan nilai Ilihiyah. Rumah tangga merupakan fondasi terhadap perkembangan agama bagi anak. Anak pertama sekali berkenalan dengan ibu dan ayah, saudara-saudara serta anggota keluarga lainnya. Melalui komunikasi itulah terjadi proses penerimaan pengetahuan dan nilai-nilai apa saja yang hidup dan berkembang di lingkungan keluarga. Semua yang diterima dalam fase awal akan menjadi referensi kepribadian anak pada masa-masa selanjutnya. Oleh sebab itu, keluarga dituntut untuk merealisasikan nilai-nilai yang positif, nilai-nilai keagamaan, sehingga terbina kepribadian anak yang baik pula

Dalam pola asuh orangtua terhadap anak terdapat tiga tipe kepemimpinan, yaitu demokratis, otoriter dan laissez faire. Dari ketiga tipe kepemimpinan tersebut, seorang anak dapat tumbuh berkembang sesuai yang pola asuh orangtua. Dari sinilah dalam pola asuh orangtua sangat mempengaruhi sikap dan perilaku yang dimiliki oleh anak sehingga dalam lembaga pendidikan sekolah mereka memiliki karakteristik yang berbeda-beda.
\end{abstract}

Kata Kunci: Pendidikan Nilai, Keluarga, Pola Asuh

\section{Pendahuluan}

Dalam kehidupan berumah tangga, orangtua memiliki peran penting bagi anak-anak. Untuk terjalinnya hubungan baik tentu memiliki banyak faktor yang mempengaruhinya. Misalnya, faktor pendidikan, kasih sayang, profesi, pemahaman terhadap norma agama, dan mobilitas orangtua. Hubungan yang baik antara dan anak tidak hanya diukur dengan pemenuhan kebutuhan materil saja, tetapi kebutuhan mental spiritual merupakan ukuran keberhasilan dalam menciptakan hubungan tersebut. Masalah kasih sayang yang diberikan orangtua terhadap anaknya adalah faktor yang sangat penting dalam keluarga. Tidak terpenuhinya kebutuhan kasih sayang dan seringnya orangtua tidak berada di rumah menyebabkan hubungan dengan anak kurang memiliki kedekatan.

Orangtua sebagai pemimpin adalah faktor penentu dalam menciptakan keakraban hubungan dalam keluarga. Tipe kepemimpinan yang diberlakukan dalam keluarga akan memberikan suasana tertentu dengan segala dinamikanya. 


\section{Pendidikan Dalam Keluarga \\ Hidayatus Syarifah}

Interaksi yang berlangsung pun bermacam-macam bentuknya. Oleh karena itu, hampir tidak terbantah, bahwa karakteristik seorang pemimpin akan menentukan pola komunikasi yang berlangsung dalam kehidupan keluarga. Kehidupan keluarga yang dipimpin oleh seorang pemimpin otoriter akan melahirkan suasana kehidupan keluarga yang berbeda dengan kehidupan keluarga yang dipimpin oleh seorang pemimpin demokratis. Perbedaan itu disebabkan adanya perbedaan karakteristik yang dimiliki oleh kedua tipe kepemimpinan di atas.

Persoalan muncul ketika kepemimpinan yang diterapkan oleh orangtua tidak mampu menciptakan suasana kehidupan keluarga yang kondusif. Suasana kehidupan keluarga yang tidak kondusif itu, misalnya seringnya terjadi konflik antara orangtua dan anak. Kesenjangan demi kesenjangan selalu terjadi. Komunikasi yang baik pada akhirnya sukar diciptakan. Inilah awal kehancuran hubungan antara orangtua dan anak dalam keluarga. Kegagalan orangtua dalam mendidik anak yang selama ini terjadi, bukan tidak mungkin disebabkan komunikasi yang dibangun beralasan kesenjangan tanpa memperhatikan sejumlah etika komunikasi. Padahal etika komunikasi sangat penting dalam rangka mengakrabkan hubungan orangtua dengan anak. Komunikasi keluarga yang bagaimana pun bentuknya harus memperhatikan etikan komunikasi. Dari hal inilah penulis akan memaparkan dan mengemukakan pendapat yang disesuaikan dengan pendidikan keluarga dalam Islam.

\section{Keluarga Sebagai Institusi}

Keluarga adalah sebagai sebuah institusi yang terbentuk karena ikatan perkawinan. Di dalamnya hidup bersama pasangan suami-istri secara sah karena pernikahan. Mereka hidup bersama sehidup semati, ringan sama dijinjing, berat sama dipikul, selalu rukun dan damai dengan suatu tekad dan cita-cita untuk membentuk keluarga bahagia dan sejahtera lahir dan batin.

Pengertian keluarga dapat ditinjau dari dimensi hubungan darah dan hubungan sosial. Keluarga dalam dimensi hubungan darah merupakan suatu kesatuan yang diikat oleh hubungan darah antara satu dengan lainnya. Berdasarkan dimensi hubungan darah ini, keluarga dapat dibedakan menjadi keluarga besar dan keluarga inti. Keluarga adalah kelompok primer yang paling penting dalam masyarakat. Sedangkan dalam dimensi hubungan sosial, keluarga merupakan suatu kesatuan yang diikat oleh adanya saling berhubungan atau interaksi dan saling mempengaruhi antara satu dengan lainnya, walaupun di antara meraka tidak terdapat hubungan darah. (Shochib, 1998:7)

Tetapi dalam konteks keluarga inti, menurut Soelaeman, secara psikologis, keluarga adalah sekumpulan orang yang hidup bersama dalam tempat tinggal bersama dan masing-masing anggota merasakan adanya pertautan batin sehingga terjadi saling mempengaruhi, saling memperhatikan, dan saling menyerahkan diri. Sedangkan dalam pengertian pedagogis, keluarga adalah satu persekutuan hidup yang dijalin oleh kasih sayang antara pasangan dua jenis manusia yang dikukuhkan 
P-ISSN : 2541-3686

dengan pernikahan, yang bermaksud untuk saling menyempurnakan diri. (Shochib, 1998:7)

Pada dasarnya keluarga adalah sebuah komunitas dalam "satu atap". Kesadaran untuk hidup bersama dalam satu atap sebagai suami-istri, saling interaksi, dan berpotensi memiliki anak akhirnya membentuk komunitas baru yang disebut keluarga. Karenanya keluarga pun dapat diberi batasan sebagai sebuah group yang terbentuk dari perhubungan laki-laki dan wanita, perhubungan mana sedikit banyak berlangsung lama untuk menciptakan dan membesarkan anak-anak. Jadi, keluarga dalam bentuk murni merupakan satu kesatuan sosial yang terdiri dari suami, istri dan anak-anak yang belum dewasa. Satuan ini mempunyai sifat-sifat tertentu yang sama, di mana saja dalam satuan masyarakat manusia. (Hartono, 1993:79)

Sifat-sifat keluarga yang terpenting adalah hubungan suami-istri, bentuk perkawinan di mana suami-istri diadakan dan dipelihara, susunan nama-nama dan istilah termasuk cara menghitung keturunan, milik atau harta benda keluarga, dan pada umumnya keluarga itu mempunyai tempat tinggal bersama.(Hartono, 1993:79)

Ketika sebuah keluarga terbentuk, komunitas baru karena hubungan darah pun terbentuk pula. Di dalamnya ada suami, istri dan anak sebagai penghuninya. Saling berhubungan, saling berinteraksi di antara mereka melahirkan dinamika kelompok karena berbagai kepentingan, yang terkadang bisa memicu konflik dalam keluarga. Misalnya konflik antara suami-istri, konflik antara ayah dan anak, konflik antara ibu dan anak, dan konflik antara anak dan anak, bahkan konflik antara ayah, ibu dan anak.

Ketika konflik lahir, keluarga bahagia dan sejahtera sebagai suatu cita-cita bagi pasangan suami-istri sukar diwujudkan. Penyebabnya bisa karena perbedaan pandangan, karena perbedaan latar belakang kehidupan, karena masalah ekonomi, karena harga diri, karena intervensi orang ketiga dalam masalah keluarga, dan sebagainya. Siapa pun orangnya dan bagaimana pun situasi dan keadaannya, suatu keluarga tidak ingin ada konflik dalam keluarga mereka, karena hal itu disadari atau tidak dapat mengancam keutuhan keluarga. Tetapi pada umumnya konflik ringan dalam keluarga selalu saja ada dan hal itu sukar untuk dihindari. Jadi, yang terpenting yaitu bagaimana agar konflik itu tidak sampai memicu kehancuran keutuhan keluarga.

Oleh karena itu, konflik dalam keluarga harus diminimalkan untuk mewujudkan keluarga seimbang. Keluarga seimbang adalah keluarga yang ditandai oleh keharmonisan hubungan (relasi) antara ayah dan ibu, antara ayah dan anak, serta antara ibu dan anak. Setiap anggota keluarga tahu tugas dan tanggung jawab masing-masing dan dapat dipercaya. (Shochib, 1998:7)

\section{Fungsi Keluarga}

Pada hakikatnya, keluarga adalah unit terkecil dalam masyarakat yang terdiri dari suami-istri, atau suami, istri dan anak, atau ayah dan anaknya, atau ibu dan 


\section{Pendidikan Dalam Keluarga \\ Hidayatus Syarifah}

anaknya. hidup berkeluarga sebagai pasangan suami-istri tidak sembarangan. Namun nyatanya dalam kasus tertentu masih ada orangtua yang menikahkan anaknya dalam keadaan usia dini. Padahal anaknya belum siap lahir dan batin. Penyaluran nafsu seksual secara sah menurut ajaran agama melalui perkawinan bukanlah tujuan utama. Karena masih ada tujuan lain yang lebih mulia yang ingin dicapai, yaitu ingin membentuk keluarga sejahtera lahir dan batin.

Dalam peraturan pemerintah RI No. 21 tahun 1994 tentang penyelenggaraan pembangunan keluarga sejahtera, bab 1 pasal 1 ayat 2, disebutkan bahwa: keluarga sejahtera adalah keluarga yang dibentuk berdasarkan atas perkawinan yang sah, mampu memenuhi kebutuhan hidup spiritual dan materil yang layak, bertakwa kepada Tuhan Yang Maha Esa, memiliki hubungan yang serasi, selaras, dan seimbang antara anggota dan antara keluarga dengan masyarakat dan lingkungan. ( Peraturan Pemerintah RI No. 21 tahun 1994, tentang Penyelenggaraan Pembangunan Keluarga Sejahtera, Bab 1 Pasal 1 Ayat 2.)

Untuk menciptakan keluarga sejahtera tidak mudah. Kaya atau miskin bukan satu-satunya indikator untuk menilai sejahtera atau tidak suatu keluarga. Buktinya, cukup banyak ditemukan keluarga yang kaya secara ekonomi di tengah kehidupan masyarakat, tetapi belum mendapatkan kebahagiaan. Tetapi, tidak mustahil dalam keluarga yang miskin secara ekonomi ditemukan kebahagiaan. Oleh karena itu, kaya atau miskin bukan suatu jaminan untuk menilai kualitas suatu keluarga. Karena banyak aspek lain yang ikut menentukan, yaitu aspek pendidikan, kesehatan, budaya, kemandirian keluarga, dan mental spiritual serta nilai-nilai agama yang merupakan dasar untuk mencapai keluarga sejahtera. Sesuai dengan hadis Ibnu Mas'ud, bahwa Nabi Shallallahu 'Alaihi Wasallam bersabda:

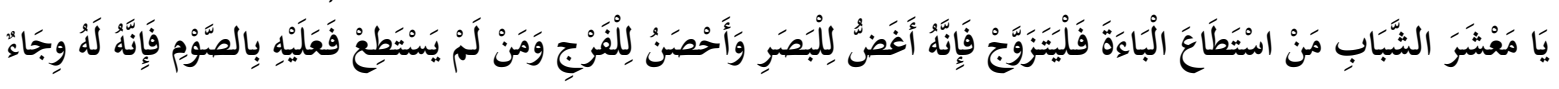

Artinya: "Wahai para pemuda, barangsiapa di antara kalian telah mampu serta berkeinginan untuk menikah, maka hendaklah ia menikah. Karena sesungguhnya pernikahan itu dapat menundukkan pandangan dan memelihara kemaluan. Dan barangsiapa tidak mampu, maka hendaklah ia berpuasa, karena sesungguhnya puasa itu dapat menjadi tameng baginya (melemahkan syahwat)." (متفق عليه)

Kata "mampu" pada hadits di atas adalah kesiapan dengan penuh tanggung jawab untuk memikul beban berumah tangga, siap secara konsisten berikhtiar dalam memenuhi kewajiban dalam mensejahterakan keluarga.

Dalam rangka untuk membangun keluarga berkualitas tidak terlepas dari usaha anggota keluarga untuk mengembangkan keluarga yang berkualitas yang diarahkan pada terwujudnya kualitas keluarga yang bercirikan kemandirian keluarga dan ketahanan keluarga. Sedangkan penyelenggaraan pengembangan keluarga yang berkualitas ditujukan agar keluarga dapat memenuhi kebutuhan spiritual dan materil, sehingga dapat menjalankan fungsi keluarga secara optimal. Sedangkan fungsi keluarga itu sendiri berkaitan langsung dengan aspek-aspek 
Volume 2 Nomor 1 Edisi Juni 2017

P-ISSN : 2541-3686

keagamaan, budaya, cinta kasih, melindungi, reproduksi, sosialisasi dan pendidikan, ekonomi, dan pembinaan lingkungan. (Shochib, 1998:7)

Keluarga adalah ladang terbaik dalam penyemaian nilai-nilai agama. Orangtua memiliki peranan yang strategis dalam mentradisikan ritual keagamaan sehingga nilai-nilai agama dapat ditanamkan ke dalam jiwa anak. Kebiasaan orangtua dalam melaksanakan ibadah, misalnya seperti shalat, puasa, infaq, dan sodaqoh menjadi suri teladan bagi anak untuk mengikuti. Di sini nilai-nilai agama dapat bersemi dengan suburnya di dalam jiwa anak. Kepribadian yang luhur dan beragama membalut jiwa anak menjadikannya insan-insan yang penuh iman dan takwa kepada Allah SWT.

Keluarga dalam konteks sosial budaya tidak bisa dipisahkan dan tradisi budaya yang tumbuh dan berkembang dalam masyarakat. Dalam konteks sosial, anak pasti hidup bermasyarakat dan bergumul dengan budaya yang ada dalam masyarakat. Dalam hal ini orangtua memiliki tanggung jawab untuk mendidik anak agar menjadi orang yang pandai hidup bermasyarakat dan hidup dengan budaya yang baik dalam masyarakat. Sebagai anggota masyarakat, anak dituntut untuk terlibat di dalamnya dan bukan sebagai penonton tanpa mengambil peranan.

Cinta kasih adalah tali jiwa antara orangtua dan anak. Cinta kasih memberikan landasan yang kokoh terhadap hubungan suami-istri, orangtua dengan anak, anak dengan anak, serta hubungan kekerabatan antar generasi sehingga keluarga menjadi wadah utama bersemainya kehidupan yang penuh cinta kasih lahir dan batin. (Djamarah, 2004:20)

Ketika cinta kasih antara orangtua dan anak hadir menyelinap ke dalam relung-relung hati, di sana terpatri keinginan untuk selalu bersama, bercengakerama dan bersenda gurau, membicarakan tentang hidup dan kehidupan. Rasa aman dalam kebersamaan mampu menumbuhkan kehangatan cinta kasih secara timbale balik. Cinta kasih yang disemai oleh orangtua mendapat sambutan hangat dari anak untuk membalasnya. Cinta pun berbalas cinta. Kasih pun berbalas kasih. Cinta kasih berbuah rindu. Rindu segala-galanya. Rindu berdekat jiwa dan rindu berdekat raga. Dalam perpisahan raga, jiwa bersatu karena kerinduan. Anak merindukan orangtua dan orangtua pun merindukan anaknya. Oleh karena itu, perpaduan cinta kasih dan kerinduan dapat mengakrabkan hubungan orangtua dengan anak dalam keluarga.

Kerinduan suami-istri untuk selalu bersama, berhubungan berdasarkan cinta kasih membuahkan hasil dengan lahirnya seorang anak. Bagi orangtua, anak adalah buah hati dan harapan di masa depan. Karenanya, sering ditemukan orangtua yang merasa sedih karena belum diberi anak oleh Allah SWT. Karena suatu sebab, misalnya, karena mandul sehingga alat reproduksi tidak berfungsi dengan baik, karena menderita kanker rahim, keguguran semasa bayi dalam kandungan, dan sebagainya. Banyak orangtua yang merasa sepi tanpa kehadiran seorang anak. Anak adalah penghibur orangtua dalam suka dan duka. Sampai kapan pun kehidupan berumah tangga itu berlangsung, suami-istri selalu mendambakan kehadiran seorang anak di sisi mereka. Tidak peduli apakah anak yang akan dilahirkan itu 


\section{Pendidikan Dalam Keluarga \\ Hidayatus Syarifah}

laki-laki atau perempuan, yang penting mendapatkan anak sebagai buah dari cinta kasih sepasang suami-istri.

Kehadiran anak di sisi orangtua tidak harus membuat orangtua terbuai dengan kebanggaan. Kebanggaan itu mungkin saja membuat orangtua terlena. Hidup dalam keterlenaan bisa menyebabkan tugas-tugas penting lainnya terlupakan. Bangga terhadap anak boleh saja, asalkan dalam batas-batas yang wajar. Karena tugas lain seperti mendidik anak masih menunggu. Mendidik anak adalah tanggung jawab orangtua. Kalaupun tugas mendidik anak dilimpahkan kepada guru di sekolah, tetapi tugas guru hanya sebatas membantu orangtua dan bukan mengambil alih tanggung jawab orangtua secara penuh. Oleh karena itu, menyerahkan sepenuhnya tugas mendidik anak kepada guru sama halnya melepaskan tanggung jawab. Itulah figur orangtua yang tidak bertanggung jawab terhadap pendidikan anaknya. Apa pun usaha yang dilakukan oleh orangtua dalam mendidik anak, yang penting anak menjadi orang yang cerdas dan bisa menyesuaikan diri dengan alam lingkungannya di masa depan. Seorang anak yang pandai menyesuaikan diri dengan alam lingkungannya, berarti dia pandai menempatkan diri secara serasi, selaras, dan seimbang sesuai dengan daya dukung alam dan lingkungan yang berubah secara dinamis.

\section{Keluarga dan Pendidikan Nilai}

Keluarga dan pendidikan tidak bisa dipisahkan. Karena selama ini telah diakui bahwa keluarga adalah salah satu dari Tri Pusat Pendidikan yang menyelenggarakan pendidikan secara kodrati. Menurut Dr. H. Kamrani Buseri, M.A. Pendidikan di lingkungan keluarga berlangsung sejak anak lahir, bahkan setelah dewasa pun orangtua masih berhak memberikan nasihatnya kepada anak sebagaimana ditegaskan dalam Al-Qur'an surah An-Nisa ayat 63:

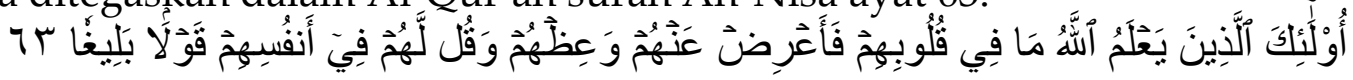

Artinya: “... karena itu berpalinglah kamu dari mereka, dan berilah mereka pelajaran, dan katakanlah kepada mereka Perkataan yang berbekas pada jiwa mereka."

Oleh karena itu, keluarga memiliki nilai strategis dalam memberikan pendidikan nilai kepada anak, terutama pendidikan nilai Ilihiyah. Rumah tangga merupakan fondasi terhadap perkembangan agama bagi anak. Anak pertama sekali berkenalan dengan ibu dan ayah, saudara-saudara serta anggota keluarga lainnya. Melalui komunikasi itulah terjadi proses penerimaan pengetahuan dan nilai-nilai apa saja yang hidup dan berkembang di lingkungan keluarga. Semua yang diterima dalam fase awal akan menjadi referensi kepribadian anak pada masa-masa selanjutnya. Oleh sebab itu, keluarga dituntut untuk merealisasikan nilai-nilai yang positif, nilai-nilai keagamaan, sehingga terbina kepribadian anak yang baik pula. (Kamrani, 2003:29) 
Walaupun begitu, disadari atau tidak, dakam kehidupan sekarang telah terjadi pergeseran nilai dalam memandang status keluarga. Jika di masa lalu ukuran status keluarga tinggi adalah kesalehan, tetapi kini orangtua umumnya memandang status keluarga yang tinggi adalah kepemilikan harta kekayaan. Sekarang budaya materil atau budaya kering nilai keagamaan telah menggeser budaya spiritual. Banyak indikator yang menunjukkan bahwa pergeseran nilai itu memang telah terjadi dalam keluarga. Misalnya, anak-anak sekarang lebih senang mendengarkan lagu-lagu pop Indonesia, atau lagu-lagu percintaan yang saran pesan-pesan keduniaan daripada mendengarkan nyanyian yang berisikan puji-pujian kepada Allah SWT.

Kehidupan keluarga sekarang jauh berbeda dengan kehidupan keluarga di masa lalu. Tradisi keluarga di masa lalu lebih kental dengan nuansa keagamaan. Kebiasaan menbaca Al-Qur'an setelah shalat Maghrib sering terdengar di dalam rumah. Tadarus Al-Qur'an merupakan bagian dari kehidupan warga masyarakat. Mendengar ceramah agama, mengunjungi tabligh akbar, menghadiri MTQ (Musabaqoh Tilawatil Qur'an) adalah kegemaran mereka walaupun harus berjalan kaki, karena penyelenggaraannya cukup jauh dari rumah kediaman mereka. Kini kegemaran orangtua dan anak menghadiri kegiatan MTQ jauh sekali berkurang. (Shihab, 1998:30) Sedikit sekali warga masyarakat yang mau menyaksikan, kalah bersaing dengan kegiatan konser Indonesian Idol, konser band dan dangdut yang kini sedang ramai digelar di mana-mana. Padahal dampak positif dari kegiatan MTQ tersebut dapat dirasakan baik tingkat nasional, provinsi, kabupaten, dan kecamatan oleh warga masyarakat. Selain itu, ada lagi kebiasaan yang baik yang mulai ditinggalkan oleh orangtua padahal berdampak positif terhadap perkembangan agama anak, yaitu kebiasaan melantunkan nyanyian yang bernafaskan agama atau puji-pujian terhadap Allah SWT atau membaca syair-syair yang berisi shalawat kepada Nabi Muhammad SAW. Ketika seorang ibu akan menidurkan anaknya di dalam ayunan.

Kehidupan keluarga sekarang pada umumnya lebih banyak terpedaya oleh tipu daya duniawi. Mengaku beragama Islam, tetapi tidak atau kurang membaca AlQur'an. Memiliki Al-Qur'an bukannya dibaca, tetapi hanya dijadikan pajangan. Bahkan Al-Qur'an itu berdebu, karena lama tersimpan, tidak pernah dibaca. Inilah potret keluarga yang miskin tradisi keagamaan.

Kini sudah waktunya orangtua menyadari dan mengembalikan fungsi keluarga di bidang pendidikan agama yang selama ini terabaikan. Pendidikan ibadah shalat, pendidikan membaca al-Qur'an harus menjadi tradisi dalam kehidupan keluarga. Sudah saatnya meninggalkan budaya barat dalam bersikap dan berperilaku. Mengidolakan dan bahkan meneladani sikap dan perilaku jahiliyah dan selebritis adalah tidak benar dalam pandangan agama. Karena semua itu sangat menyesatkan. Bukankah masih banyak tokoh dan pejuang Islam yang bisa diteladani. Profil khalifah Abu Bakar Siddiq, khalifah Umar bin Khattab, khalifah Utsman bin Affan, dan khalifah Ali bin Abi Thalib adalah para tokoh dan pejuang 


\section{Pendidikan Dalam Keluarga \\ Hidayatus Syarifah}

Islam yang bisa diteladani. Selain itu, selogan-selogan yang dipajang di dinding rumah sebaiknya bernapaskan keagamaan. Selogan-selogan itu misalnya "shalatlah kamu sebelum dishalatkan orang lain", "sudahkah Anda shalat?", sudahkah Anda membaca Al-Qur'an", dan sebagainya.

Budaya silaturrahim antar keluarga kini sangat jarang terlihat sehingga jangan heran bila anak-anak tidak mengenal siapa keluarganya, kerabat, dan handai tolan. Berbagai kesibukan selalu dijadikan sebagai faktor penyebab, padahal pada waktu tertentu masih ada peluang waktu untuk dimanfaatkan bersilaturrahim. Tetapi yang terjadi adalah orangtua membawa anak-anak mereka pergi ke taman rekreasi, ke objek-objek wisata atau ke tempat hiburan lainnya. Dampak kehidupan modern yang individualistik memang telah mengubah tatanan kehidupan keluarga sehingga tradisi positif yang sarat nilai-nilai agama seperti budaya silaturrahim semakin ditinggalkan. Yang ada hanyalah budaya silaturrahim ketika Hari Raya Idul Fitri maupun Hari Raya Idul Adha atau silaturrahim ada sesuatu. Tetapi, hal itu masih lebih baik daripada tidak ada sama sekali. Namun akan lebih baiknya lagi bila frekuensi silaturrahim ditingkatkan. Bukankah menyambung tali silaturrahim yang hampir putus dengan membudayakan saling mengunjungi antar keluarga sangat dianjurkan oleh agama. Kinilah saatnya untuk berbuatyang terbaik bagi anak. Jangan menunggu besok, sebab bila tradisi silaturrahim hilang, dampak negatifnya tidak dapat dielakkan.

\section{Pola Asuh Orangtua dalam Keluarga}

Pendidikan dalam keluarga memiliki nilai strategis dalam pembentukan kepribadian anak. Sejak kecil anak sudah mendapat pendidikan dari kedua orangtuanya melalui keteladanan dan kebiasaan hidup sehari-hari dalam keluarga. Baik tidaknya keteladanan yang diberikan dan bagaimana kebiasaan hidup orangtua sehari-hari dalam keluarga akan mempengaruhi perkembangan jiwa anak. Keteladanan dan kebiasaan yang orangtua tampilkan dalam bersikap dan berperilaku tidak terlepas dari perhatian dan pengamatan anak. Meniru kebiasaan hidup orangtua adalah suatu hal yang sering anak lakukan, karena memang pada masa perkembangannya, anak selalu ingin menuruti apa-apa yang orangtua lakukan. Anak selalu ingin meniru ini dalam pendidikan dikenal dengan istilah anak belajar melalui imitasi. (Djamarah, 2004:25)

Pendapat di atas tidak dapat dibantah, karena memang dalam kenyataannya anak suka meniru sikap dan perilaku orangtua dalam keluarga. Dorothy Law Nolte sangat mendukung pendapat di atas. Melalui sajaknya yang berjudul "anak belajar dari kehidupan", dia mengatakan bahwa: jika anak dibesarkan dengan celaan, ia belajar memaki. Jika anak dibesarkan dengan permusuhan, ia belajar berkelahi. Jika anak dibesarkan dengan cemoohan, ia belajar rendah diri. Jika anak dibesarkan dengan penghinaan, ia belajar menyesali diri. Jika anak dibesarkan dengan toleransi, ia belajar menahan diri. Jika anak dibesarkan dengan dorongan, ia belajar percaya diri. Jika anak dibesarkan dengan pujian, ia belajar menghargai. Jika anak 
Volume 2 Nomor 1 Edisi Juni 2017

P-ISSN : 2541-3686

dibesarkan dengan sebaik-baik perlakuan, ia belajar keadilan. Jika anak dibesarkan dengan rasa aman, ia belajar menaruh kepercayaan. Jika anak dibesarkan dengan dukungan, ia belajar menyenangi dirinya. Jika anak dibesarkan dengan kasih sayang dan persahabatan, ia belajar menemukan cinta dalam kehidupan.(Jalaludin, 2001:103)

Dalam kehidupan sehari-hari orangtua tidak hanya secara sadar, tetapi juga terkadang secara tidak sadar memberikan contoh yang kurang baik kepada anak. Misalnya, meminta tolong kepada anak dengan nada mengancam seolah orangtua di rumah sebagai bos dan bukan sebagai orangtua untuk anak-anaknya. (Ihsan, 2010:167) Tidak mau mendengarkan cerita anak tentang suatu hal, mendengarkan dengan empati berarti orangtua menempatkan dirinya pada posisi anak, sehingga anak terdorong untuk lebih terbuka. Orangtua menemani anak dalam momen kegembiraan, kesedihan, ketakutan, dan kemarahan dengan cara tidak menghakimi. Sedangkan, mendengarkan secara aktif adalah cara efektif untuk membuat anak tahu bahwa ia sedang didengarkan. Orangtua melakukan kontak mata dengan anak, memperhatikan bahasa tubuhnya, mengulang apa yang didengarnya, tidak terburuburu memberikan tanggapan, apalagi menawarkan solusi atau nasihat tanpa diminta. (Ihsan, 2010:172)

Memberi nasihat tidak pada tempatnya dan tidak pada waktu yang tepat. Menasihati anak adalah salah satu jalan dalam mendidik anak. Salah satu jalan artinya memang bukan satu-satunya jalan. Jika ia hanya menjadi satu-satunya jalan, sungguh justru nasihat menjadi tidak produktif dan bertentangan dengan tujuan nasihat itu sendiri. Semua nasihat pasti memiliki tujuan yang baik. Akan tetapi, jika tidak pandai mengelolanya, nasihat justru akan membuat anak semakin terpuruk pada keburukan. Akibat tidak melihat waktu, tempat, dan kondisi sebagian nasihat pada kenyataannya hanya lewat di telinga anak atau masuk dari telinga kanan dan keluar telinga kiri. (Ihsan, 2010:129) Berbicara kasar kepada anak, terlalu mementingkan diri sendiri, tidak mau mengakui kesalahan padahal apa yang telah dilakukan adalah salah, mengaku serba tahu padahal tidak mengetahui banyak tentang sesuatu, terlalu mencampuri urusan anak, membeda-bedakan anak, kurang memberikan kepercayaan kepada anak untuk melakukan sesuatu, dan sebagainya.

Beberapa contoh sikap dan perilaku dari orangtua yang dikemukakan di atas berimplikasi negatif terhadap perkembangan jiwa anak. Anak telah belajar banyak dari orangtuanya. Anak belum memiliki kemampuan untuk menilai, apakah yang diberikan oleh orangtuanya termasuk sikap dan perilaku yang baik atau tidak. Yang terpenting bagi anak adalah mereka telah belajar banyak hal dari sikap dan perilaku yang didemonstrasikan oleh orangtuanya. Efek negatif dari sikap dan perilaku orangtua yang demikian terhadap anak misalnya, anak memiliki sifat keras hari, keras kepala, manja, pendusta, pemalu, pemalas, dan sebagainya. Sifat-sifat anak tersebut menjadi rintangan dalam pendidikan anak selanjutnya. (Ngalim Purwanto, 1991:99-109) 


\section{Pendidikan Dalam Keluarga \\ Hidayatus Syarifah}

Semua sikap dan perilaku anak yang telah dipolesi dengan sifat-sifat tersebut di atas diakui dipengaruhi oleh pola pendidikan dalam keluarga. Dengan kata lain, pola asuh orangtua akan mempengaruhi perkembangan jiwa anak. Pola asuh orangtua di sini bersentuhan langsung dengan masalah tipe kepemimpinan orangtua dalam keluarga. Tipe kepemimpinan orangtua dalam keluarga itu bermacam-macam, sehingga pola asuh orangtua terhadap anak juga berlainan. Di satu sisi, pola asuh orangtua bersifat demokratis atau otoriter. Pada sisi lain, bersifat laissez faire atau bertipe campuran antara demokratis dan otoriter. (Djamarah, 2004:25)

Dinamika hubungan dalam keluarga dipengaruhi oleh pola kepemimpinan. Karakteristik seorang pemimpin akan menentukan pola komunikasi bagaimana yang akan berproses dalam kehidupan yang membentuk hubungan-hubungan tersebut. Menurut Cragan dan Wright, kepemimpinan adalah komunikasi yang secara positif mempengaruhi kelompok untuk bergerak ke arah tujuan kelompok. Kepemimpinan adalah faktor yang paling menentukan keefektifan komunikasi kelompok (Jalaludin,2001:165) Dinamika kelompok bagaimana akan terjadi ditentukan oleh gaya-gaya kepemimpinan. Tetapi bisa juga sebaliknya, kelompok bagaimana yang dipimpin, akan mempengaruhi pola kepemimpinan. Ternyata lahirnya gaya-gaya kepemimpinan tidak semata-mata karena pengaruh dari yang memimpin secara vertical, tetapi juga karena pengaruh dari yang dipimpin secara horizontal. Tipe-tipe kepemimpinan itu pula yang melahirkan bermacam-macam sikap dan perilaku seseorang dalam memimpin kelompoknya. Karenanya, cara-cara kepemimpinan yang berlainan yang ditunjukkan oleh seorang pemimpin kepada bawahannya mempunyai akibat-akibat berlainan terhadap interaksi kelompok (Gerung, 2000:131) Cara-ara kepemimpinan itu bisa otoriter, demokrasi, atau laissez faire. (Hadari Nawawi, 1988:91)

Tipe-tipe kepemimpinan di atas sering mewarnai cara-cara orangtua memimpin anggota keluarga dalam etnik keluarga tertentu dan berefek pada komunikasi antara orangtua dan anak. Hal ini tidak dapat dibantah, karena memang diakui bahwa kepemimpinan dapat mempengaruhi proses komunikasi. Bentukbentuk komunikasi bagaimana yang terjadi bergantung dari pola kepemimpinan yang dilakukan oleh orangtua kepada anak-anaknya dalam keluarga. Interaksi yang terjadi pun bermacam-macam bentuknya, yang pada akhirnya akan memberikan pengaruh pada perilaku pendidikan yang dilakukan oleh orangtua.

Dalam beberapa etnik keluarga, kepemimpinan orangtua yang biasanya muncul sering berlainan. Cara kepemimpinan orangtua dalam keluarga yang sering terjadi adalah pemimpin demokratis, otoriter, dan laissez faire. Hasil penelitian yang telah dilakukan oleh Taufiqurrahman, dosen Fakultas Tarbiyah IAIN Antasari Banjarmasin, telah membuktikan bahwa terdapat kepemimpinan orangtua yang demokratis, otoriter, dan laissez faire dalam suatu keluarga. Disbanding kepemimpinan orangtua yang otoriter dan laissez faire, kepemimpinan orangtua yang demokratis lebih dominan ada dalam suatu keluarga. (Khazanah, 2003:608) 
Cara kepemimpinan orangtua secara otoriter akan berbeda dengan cara kepemimpinan orangtua secara demokratis. Kepemimpinan secara laissez faire akan menunjukkan perilaku kepemimpinan orangtua yang berlainan dengan kedua pola kepemimpinan di atas.

Kepemimpinan otoriter ditandai dengan keputusan dan kebijakan yang seluruhnya ditentukan oleh pemimpin yaitu orangtua. Kepemimpinan demokratis menampilkan pemimpin yang mendorong dan membantu anggota keluarga untuk membicarakan dan memutuskan semua kebijakan. Kepemimpinan laissez faire memberikan kebebasan penuh bagi anggota keluarga untuk mengambil keputusan individual dengan partisipasi orangtua yang minimal (Jalaludin, 2001:165)

While dan Lippit telah melakukan eksperimen tentang pengaruhgaya kepemimpinan pada produktivitas dan kepuasan. Penelitian tersebut dilakukan terhadap empat kelompok anak-anak dalam suasana alamiah. Mereka menemukan bahwa kepemimpinan otoriter menimbulkan permusuhan, agresi, dan sekaligus perilaku submisif (bersikap patuh). Di sini, tampak lebih banyak ketergantungan dan kurang kemandirian, di samping adanya kekecewaan yang tersembunyi. Kepemimpinan demokratis terbukti paling efisien, dan menghasilkan kualitas kerja yang lebih tinggi daripada kepemimpinan otoriter.

Dari segi komunikasi, White dan Lippit memberikan kesimpulan bahwa pemimpin demokratis cenderung tidak seberapa banyak memberikan saran, mempunyai disiplin diri, (kemungkinan berpotensi) tidak kritis, dan bersikap objektif dalam hubungannya dengan anggota-anggota kelompok. Pemimpin otokratis cenderung banyak memberikan perintah, berkuasa untuk menyetujui dan memuji orang, dan pada umumnya agak kritis. Pemimpin laissez faire hanya memiliki kelebihan dalam menyampaikan informasi saja. Kepemimpinan otoriter dapat lebih produktif pada situasi tertentu daripada kepemimpinan demokratis. (Jalaludin, 2001:165)

Cara-cara kepemimpinan mana yang dipilih tergantung dari berbagai pertimbangan tanpa mengabaikan kemungkinan efek yang ditimbulkan dari kebijakan yang dilakukan. Tetapi yang terpenting adalah bagaimana agar proses mempengaruhi aktivitas individu atau kelompok diarahkan untuk mencapai tujuan dalam situasi tertentu. Dalam hal ini ada tiga faktor yang mempengaruhi proses kepemimpinan, yaitu pemimpin, kelompok, dan situasi. (Indriyo, 2000:128)

Dalam konteks pendidikan dalam keluarga, maka pola kepemimpinan orangtua dapat memberikan pengaruh yang signifikan terhadap pendidikan anak. Sebab ketiga tipe kepemimpinan orangtua tersebut sudah pasti akan melahirkan pola komunikasi yang berbeda sehingga suasana kehidupan keluarga yang terbentuk pun berlainan. Dalam kenyataan di masyarakat menunjukkan bahwa dalam etnik keluarga tertentu, karena cara orangtua mendidik anak-anak mereka bermacam-macam, maka lahirlah anak-anak dengan karakteristik mereka masingmasing. Suatu keluarga yang agamis dan akrab dengan ritual keagamaan cenderung 


\section{Pendidikan Dalam Keluarga \\ Hidayatus Syarifah}

melahirkan anak yang taat pada ajaran agama. Sedangkan suatu keluarga yang anti agama cenderung melahirkan anak yang aties.

Karena tipe kepemimpinan dapat mempengaruhi pola komunikasi, maka keharmonisan hubungan antara orangtua dan anak dalam keluarga dipengaruhi oleh kepemimpinan orangtua dengan segala kebaikan dan kekurangannya. Tetapi, tipe kepemimpinan yang bagaimana pun yang digunakan oleh orangtua untuk mempengaruhi anak atau mendidik anak, yang pasti adalah bahwa setiap kali orangtua melakukan komunikasi kepada anak selalu menciptakan hubungan yang berbeda.

Berdasarkan uraian di atas, maka tipe kepemimpinan orangtua yang bagaimana pun bentuk dan sifatnya, akan mempengaruhi pola komunikasi antara anggota keluarga, yaitu antara ayah, ibu dan anak. Sistem interaksi yang terbentuk melahirkan hubungan dengan intensitas yang bervariasi antara ayah, ibu dan anak dalam keluarga. Dalam masyarakat tradisional misalnya, hubungan kekerabatan cenderung sangat dekat. Sementara dalam masyarakat modern, hubungan kekerabatan cenderung renggang. Sikap rasa senasib sepenanggungan yang masih mentradisi dalam kehidupan di masyarakat tradisional membentuk jaringan yang rapat. Sikap individualistic yang membelenggu kehidupan masyarakat modern membentuk jaringan sosial yang renggang, sehingga hubungan kekerabatan pun semakin renggang dan kepedulian sosial tanpa pamrih semakin sulit ditemukan.

Tipe kepemimpinan orangtua yang otoriter, meski tidak disukai oleh kebanyakan orang, karena menganggap dirinya sebagai orangtua paling berkuasa, paling mengetahui dalam segala hal, tetapi dalam etnik keluarga tertentu masih terlihat dipraktikkan. Dalam praktiknya tipe kepemimpinan orangtua yang otoriter cenderung ingin menguasai anak. Perintahnya harus selalu dituruti dan tidak boleh dibantah. Anak kurang diberikan kesempatan untuk memberikan tanggapan dalam bentuk penjelasan, pandangan atau saran-saran. Tanpa melihat kepentingan pribadi anak, yang penting instruksi orangtua harus dituruti.

Tipe kepemimpinan orangtua yang otoriter selain ada keuntungannya, juga ada kelemahannya. Anak yang selalu taat perintah adalah di antara keuntungannya. Sedangkan kelemahannya adalah kehidupan anak statis, hanya menunggu perintah, kurang kreatif, pasif, miskin inisiatif, tidak percaya diri, dan sebagainya. (Ngalim Purwanto, 1991:142)

Berbeda dengan tipe kepemimpinan demokratis atau otoriter, tipe kepemimpinan orangtua yang laissez faire memberikan cukup kebebasan kapada anak untuk mengambil kebijakan sendiri dalam menghadapi sesuatu. Orangtua menyerahkan segala sesuatunya kepada anak; entah dalam menentukan tujuan, langkah-langkah dari suatu kegiatan yang akan diambil, sarana atau alat yang akan dipergunakan. Tipe kepemimpinan orangtua yang cenderung liberal ini membuat orangtua bersifat pasif dan tidak ada inisiatif, karena orangtua tidak terlibat langsung dalam kegiatan anak. Orangtua seolah-olah hanya bertindak sebagai penonton, meskipun ia berada di tengah-tengah anak-anaknya dalam keluarga. (Ngalim Purwanto, 1991:143) 
Selain itu terdapat sifat-sifat yang harus dimiliki oleh orangtua sebagai seorang pemimpin dalam keluarga., yaitu energy jasmani dan mental, kesadaran akan tujuan dan arah pendidikan anak, antusiasme (semangat, kegairahan, dan kegembiraan yang besar), keramahan dan kecintaan, integritas kepribadian (keutuhan, kejujuran, dan ketulusan hati), penguasaan teknis mendidik anak, ketegasan dalam mengambil keputusan, cerdas, memiliki kepercayaan diri, stabilitas emosi, kemampuan mengenal karakteristik anak, objektif, dan ada dorongan pribadi. (Kartini, 1994:38-43)

\section{Orangtua dan Anak dalam Keluarga}

Orangtua dan anak adalah satu ikatan dalam jiwa. Dalam keterpisahan raga, jiwa mereka bersatu dalam ikatan keabadian. Tidak seorang pun dapat menceraiberaikannya. Ikatan itu dalam bentuk hubungan emosional antara anak dan orangtua yang tercermin dalam perilaku.(Enoch Markum, 1985:41) Meskipun suatu saat misalnya, ayah dan ibu mereka sudah bercerai karena suatu sebab, tetapi hubungan emosional antara orangtua dan anak tidak pernah terputus. Sejahat-jahat ayah adalah tetap orangtua yang harus dihormati. Lebih-lebih lagi terhadap ibu yang telah melahirkan dan membesarkan. Bahkan dalam perbedaan keyakinan agama sekalipun antara orangtua dan anak, maka seorang anak tetap diwajibkan menghormati orangtua sampai kapanpun.

Setiap orangtua yang memiliki anak selalu ingin memelihara, membesarkan, dan mendidiknya. Seorang ibu yang melahirkan anak tanpa ayah pun memiliki naluri untuk memelihara, membesarkan, dan mendidiknya, meski terkadang harus menanggung beban malu yang berkepanjangan. Sebab kehormatan keluarga salah satunya juga ditentukan oleh bagaimana sikap dan perilaku anak dalam menjaga nama baik keluarga. Lewat sikap dan perilaku anak nama baik keluarga dipertaruhkan.

Orangtua dan anak dalam suatu keluarga memiliki kedudukan yang berbeda. Dalam pandangan orangtua, anak adalah buah hati dan tumpuan di masa dapan yang harus dipelihara dan dididik. Memeliharanya dari segala marabahaya dan mendidiknya agar menjadi anak yang cerdas. Itulah sifat fitrah orangtua. Sedangkan sifat-sifat fitrah orangtua yang lainnya, seperti diungkapkan oleh $\mathrm{M}$. Thalib, adalah senang mempunyai anak, senang anak-anaknya shalih, berusaha menempatkan anak di tempat yang baik, sedih melihat anaknya lemah atau hidup miskin, memohon kepada Allah bagi kebaikan anaknya, lebih memikirkan keselamatan anak daripada dirinya pada saat terjadi bencana, senang mempunyai anak yang bisa dibanggakan, cenderung lebih mencintai anak tertentu, menghendaki anaknya berbakti kepadanya, bersabar menghadapi perilaku buruk anaknya. (Thalib, 1997:7)

Sedangkan di antara tipe-tipe orangtua menurut $\mathrm{M}$. Thalib adalah penyantun dan pengayom, berwibawa dan pemurah, pemurah kepada istri, lemah lembut, dermawan, egois, emosional, mau menang sendiri, dan kejam. (Thalib, 1999:7) 


\section{Pendidikan Dalam Keluarga \\ Hidayatus Syarifah}

\section{Tanggung Jawab Orangtua dalam Mendidik Anak}

Keluarga adalah suatu institusi yang terbentuk karena ikatan pernikahan antara sepasang suami-istri untuk hidup bersama, setia, sekata, seiring dan setujuan, dalam membina mahligai rumah tangga untuk mencapai keluarga sakinah dalam lindungan dan ridha Allah SWT. Di dalamnya selain ada ayah dan ibu, juga ada anak yang menjadi tanggung jawab orangtua.

Tanggung jawab orangtua terhadap anaknya tampil dalam bentuk yang bermacam-macam. Secara garis besar, bila dibutiri, maka tanggung jawab orangtua terhadap anaknya adalah bergembira menyambut kalahiran anak, memberi nama yang baik, memperlakukan dengan lembut dan kasih sayang, menanamkan rasa cinta sesama anak, memberikan pendidikan akhlak, menanamkan akidah tauhid, melatih anakmengerjakan shalat, berlaku adil, memperhatikan teman anak, menghormati anak, memberikan hiburan, mencegah perbuatan bebas, menjauhkan anak dari hal-hal porno (baik pornoaksi maupun pernografi), menempatkan dalam lingkungan yang baik, memperkenalkan kerabat kepada anak, mendidik bertetangga dan bermasyarakat.(Thalib, 1995:7-9) Sementara itu, Abdullah Ulwan membagi tanggung jawab orangtua dalam mendidik bersentuhan langsung dengan pendidikan iman, pendidikan moral, pendidikan fisik, pendidikan rasio atau akal, pendidikan kajiwaan, pendidikan sosial, dan pendidikan seksual. (Ulwan, 1995:148)

Konteksnya dengan tanggung jawab orangtua dalam pendidikan, maka orangtua adalah pendidik pertama dan utama dalam keluarga. Bagi anak, orangtua adalah model yang harus ditiru dan diteladani. Sebagai model, orangtua seharusnya memberikan contoh yang terbaik bagi anak dalam keluarga. Sikap dan perilaku orangtua harus mencerminkan akhlak yang mulia. Oleh karena itu, Islam mengajarkan kepada orangtua agar selalu mengajarkan sesuatu yang baik-baik saja kepada anak mereka. dalam salah satu hadis yang diriwayatkan oleh Abdur Razzaq Sa'id bin Mansur, Rasulullah SAW bersabda: (Ulwan, 1995:148)

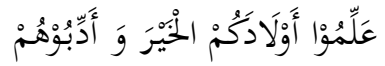

Artinya: "Ajarkanlah kebaikan kepada anak-anak kamu dan didiklah mereka dengan budi pekerti yang baik".

Dalam hadis lain, dari Ibnu Abbas r.a, Baihaqi meriwayatkan, Rasulullah SAW bersabda: (Ulwan, 1995:148)

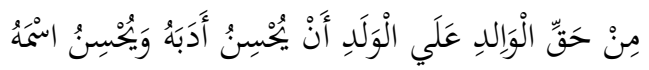

Artinya: "Di antara hak orangtua terhadap anaknya adalah mendidiknya dengan budi pekerti yang baik dan memberinya nama yang baik."

Pembentukan budi pekerti yang baik adalah tujuan utama dalam pendidikan Islam. Karena dengan budi pekerti itulah tercermin pribadi yang mulia. Sedangkan pribadi yang mulia itu adalah pribadi yang utama yang ingin dicapai dalam 
P-ISSN : 2541-3686

mendidik anak dalam keluarga. Namun sayangnya, tidak semua orangtua dapat melakukannya. Banyak faktor yang menjadi penyebabnya, misalnya orangtua yang sibuk dan bekerja keras siang dan malam dalam hidupnya untuk memenuhi kebutuhan materi anak-anaknya, waktunya dihabiskan di luar rumah, jauh dari keluarga, tidak sempat mengawasi perkembangan anaknya, dan bahkan tidak punya waktu untuk memberikan bimbingan, sehingga pendidikan akhlak bagi anak-anaknya terabaikan.

Akhirnya, apa pun alasannya, mendidik anak adalah tanggung jawab orangtua dalam keluarga. Oleh karena itu, sesibuk apa pun pekerjaan yang harus diselesaikan, meluangkan waktu demi pendidikan anak adalah lebih baik. Bukankah orangtua yang bijaksana adalah orangtua yang lebih mendahulukan pendidikan anak daripada mengurusi pekerjaan siang dan malam.

\section{Beberapa Kesalahan Pendidikan}

Dalam keluarga orangtua bertanggung jawab memberikan pendidikan kepada anaknya dengan pendidikan yang baik berdasarkan nilai-nilai akhlak dan spiritual yang luhur. Namun sayangnya, tidak semua orangtua dapat melakukannya. Buktinya dalam kehidupan di masyarakat sering ditemukan anak-anak nakal dengan sikap dan perilaku jahiliyah yang tidak hanya terlibat dalam perkelahian, tetapi juga terlibat dalam pergaulan bebas, perjudian, pencurian, narkoba, dan sebagainya.

Masalah perilaku seksual anak misalnya, terutama remaja yang berpacaran, tidak hanya ditemukan di masa lalu, sekarang juga masih ditemukan dalam pergaulan antar remaja. Hasil penelitian terhadap remaja di Jakarta telah membuktikan, bahwa dalam berpacaran, mencium bibir, memegang buah dada, memegang alat kelamin lawan jenis, dan bahkan melakukan senggama, sepertinya merupakan hal biasa bagi para remaja. Bahkan ada di antara mereka yang merasa senang melakukannya.(Sarlito, 1981:27) Ironis memang. Tetapi inilah kenyataannya objektif dalam kehidupan di kalangan remaja. Tentu saja masalah ini tidak berdiri sendiri, tetapi banyak faktor yang menjadi penyebabnya, yang antara lain karena keluarga yang broken home, kurangnya pendidikan agama, miskinnya pendidikan akhlak, atau karena kesalahan memilih teman.

Namun, dari sekian banyak faktor penyebab itu, penyebab utamanya adalah karena kurangnya pendidikan agama dan hilangnya keteladanan yang baik dari orangtua dalam keluarga. Orangtua terlalu memperhatikan kesejahteraan materi anak, sementara santapan rohani anak berdasarkan prinsip-prinsip agama, etika dan sopan santun terabaikan. (Djamarah, 2004:32) Tidak sedikit ditemukan orangtua yang merasa bangga kepada anaknya, karena anaknya memperlihatkan prestasi belajar yang tinggi dalam mata pelajaran matematika, fisika, kimia, atau bahasa Inggris. Sebaliknya, tidak jarang ditemukan orangtua yang menunjukkan sikap biasa-biasa saja atau tidak merasa sedih ketika melihat nilai pelajaran agama anaknya rendah. 


\section{Pendidikan Dalam Keluarga \\ Hidayatus Syarifah}

Orangtua seperti yang disebutkan di atas adalah orangtua yang merugi sebagaimana yang Allah SWT firmankan dalam Al-Qur'an Surat Az-Zumar ayat 15:

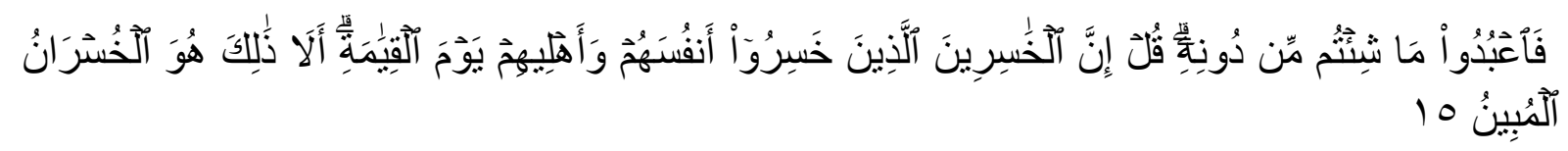

Artinya: "Sesungguhnya orang-orang yang rugi ialah orang-orang yang merugikan diri mereka sendiri dan keluarganya pada hari kiamat. ingatlah yang demikian itu adalah kerugian yang nyata."

Bila dikaji lebih jauh lagi, ternyata kesalahan orangtua dalam mendidik anak cukup banyak. Misalnya mamakai cara-cara yang tidak bijaksana, orangtua menganggap bahwa memarahi, menghardik, mencela, atau memberikan hukuman fisik dari pendidikan anak, padahal hal itu merupakan kesalahan yang besar. Sebenarnya mendidik anak tidak hanya cukup bermodalkan watak kebapakan dan keibuan tanpa didukung dengan kemampuan bagaimana cara-cara mendidik yang baik.

Dalam etnik keluarga tertentu sering ditemukan sikap dan perilaku orangtua yang memarahi, menghardik, mencela atau memberikan hukuman fisik sekehendak hati kepada anaknya jika anaknya melakukan kasalahan. Padahal penggunaan caracara seperti di atas secara psikologis mendatangkan efek negatif dari celaan misalnya, dapat melahirkan kedengkian dan dendam bagi anak yang dicela dan melahirkan sikap takabbur bagi orangtua yang melakukan celaan. Demikian juga memberikan sanksi berupa pukulan. Walaupun memukul dapat dibenarkan oleh agama, tetapi tidak bisa dilakukan di sembarang tempat di tubuh anak.

Abdullah Nasih Ulwan sependapat dengan pernyataan di atas. Dukungan itu terdapat dalam pernyataannya, bahwa di antara masalah yang hampir menjadi kesepakatan seluruh ahli pendidikan adalah bahwa jika anak diperlakukan oleh kedua orangtuanya dengan perlakuan kejam, dididik dengan pukulan yang keras, cemoohan pedas dan selalu mendapatkan penghinaan dan ejekan, maka akan menimbulkan reaksi balik yang akan tampak pada perilaku dan akhlaknya, dan gejala rasa takut serta cemas akan tampak pada tindakan-tindakan anak. Bahkan secara lebih tragis akan mengakibatkan anak terkadang berani membunuh kedua orangtuanya atau meninggalkan rumahnya demi menyelamatkan diri dari kekejaman, kezaliman, dan perlakuan yang menyakitkan.(Ulwan, 1995:129) Ternyata kesalahan pendidikan yang dilakukan oleh orangtua terhadap anaknya mendatangkan efek negatif bagi perkembangan jiwa anak dalam kehidupan selanjutnya.

\section{Simpulan}

Keluarga merupakan lembaga pertama dalam kehidupan anak. Dalam proses pendidikan keluarga anak diharapkan memiliki sikap dan perilaku yang baik dalam kehidupan sehari-hari. Karena orangtua merupakan pembimbing, pemelihara, 
RAUDHAH Proud To Be Professionals qurnal 7arbiyah? dlamiyah

Volume 2 Nomor 1 Edisi Juni 2017

P-ISSN : 2541-3686

pendidik, penasihat bagi anak-anaknya. peran orangtua sebagai pemberi teladan yang baik bagi mereka untuk dapat ditiru agar potensi mereka dapat tumbuh dan berkembang.

Dalam pola asuh orangtua terhadap anak terdapat tiga tipe kepemimpinan, yaitu demokratis, otoriter dan laissez faire. Dari ketiga tipe kepemimpinan tersebut, seorang anak dapat tumbuh berkembang sesuai yang pola asuh orangtua. Dari sinilah dalam pola asuh orangtua sangat mempengaruhi sikap dan perilaku yang dimiliki oleh anak sehingga dalam lembaga pendidikan sekolah mereka memiliki karakteristik yang berbeda-beda.

\section{DAFTAR PUSTAKA}

Buchori, Ihsan Baihaqi Ibnu. Sebelum Meminta Anak Shalih, Yuk Jadi Orangtua Shalih!, Bandung: Mizan Pustaka, 2010.

Buseri, Kamrani. Antologi Pendidikan Islam dan Dakwah Pemikiran Teoritis Praktis Kontemporer, Yogyakarta: UII Press, 2003.

Djamarah, Syaiful. Pola Komunikasi Orangtua dan Anak dalam Keluarga, Jakarta: Rineka Cipta, 2004.

Gitosudarmo, Indriyo dan Sudita, I Nyoman, Perilaku Keorganisasian, Yogyakarta: BPFE, 2000.

Hartono dan Aziz, Arnicum. Ilmu Dasar, Jakarta: Bumi Aksara, cet. III, 1993.

Ihsan Baihaqi Ibnu Buchori, Sudahkah Aku Jadi Orangtua Shalih, Bandung: Khazanah Intelektual, 2010.

Kartono, Kartini Pemimpin dan Kepemimpinan, Jakarta: RajaGrafindo Persada, 1994.

Khazanah; Majalah Ilmiah Keagamaan dan Kemasyarakatan, Vol II, No. 05 September-Oktober 2003, IAIN Antasari, Banjarmasin.

Markum, M. Enoch. Anak, Keluarga dan Masyarakat, akarta: Sinar Harapan, 1985.

M. Thalib, Memahami 20 Sifat Fitrah Orangtua, Bandung: Irsyad Baitus Salam, 1997

_Mengenal Tipe-tipe Suami, Bandung: Irsyad Baitus Salam, 1999.

— 40 Tanggung Jawab Orangtua terhadap Anak, Bandung: Irsyad Baitus Salam, 1995.

Nawawi, Hadari. Administrasi Pendidikan, Jakarta: Haji Masagung, 1988.

Peraturan Pemerintah RI No. 21 tahun 1994, tentang Penyelenggaraan Pembangunan Keluarga Sejahtera, Bab 1 Pasal 1 Ayat 2. 


\section{Hidayatus Syarifah}

Purwanto, M. Ngalim. Ilmu Pendidikan Teoritis dan Praktis, Bandung: Remaja Rosdakarya, 1991.

Rakhmat, Jalaluddin. Psikologi Komunikasi, Bandung: Remaja Rodakarya, 2001.

Sarwono, Sarlito Wirawan. Pergeseran Norma Perilaku Seksual Kaum Ramaja: Sebuah Penelitian terhadap Remaja Jakarta, Jakarta: Rajawali, 1981.

Shochib, Moh. Pola Asuh Orangtua dalam Membantu Anak Mengembangkan Disiplin Diri,Jakarta: Rineka Cipta, 1998.

Shihab, M. Quraish. Lentera Hati; Kisah dan Hikmah Kehidupan, Mizan cet. XIII, 1998.

Ulwan, Abdullah Nasih, Tarbiyatul Aulad Fil Islam, Diterjemahkan oleh Drs. Jamaludin Miri, Lc. Dengan judul "Pendidikan Anak dalam Islam", Jakarta: Pustaka Amani, 1995.

W.A. Gerung, Psikologi, Bandung: Refika Aditama, 2000. 